inadequacy of their food supply now that the game, which was formerly their subsistence, has become scarce. Here the Department has embarked on an extensive educational programme in agriculture with a scheme of assistance, for which great success is claimed. Through it some hundreds of Indians have become entirely self-supporting by agriculture within two generations. About one third of the Indians still live the traditional nomadic life in the northern hinterland with the easily moved tepee as their home and hunting and trapping as their means of subsistence.

\section{Archæological Excavations in Syria}

SIR LEONARD WoOLIEY's account of the first month's work on the British Museum's new archæo. logical site in Syria fully confirms anticipation of the nature of the evidence likely to be obtained at such a point as the mouth of the Orontes, which must have been an important centre of international and commercial intercourse from early times. Tel Sheikh Yusuf el Gharib, a low mound, so called after a local saint, on the right bank of the Orontes, he reports in The Times of June 4, has produced evidence of nine occupation levels. As virgin soil has been reached just below deposits which are dated at about the twelfth century B.c., it is evident that the mound begins with what can only be a later extension of the main settlement. Although in consequence no material of Mycenæan age or earlier is forthcoming, it has yielded finds of considerable interest and no little importance. The pottery, for example, includes possibly the finest example of Proto-Corinthian ware yet known, while the so-called 'Cypriote' ware, a class of ceramics appearing in Cyprus in the Early Iron Age without known local antecedents, occurs here rather earlier in the eighth level in such sudden abundance as to suggest a violent occupation, and possibly may eventually afford a clue to the cultural origins of this type in Asia. Especially fine examples of orientalising Agean wares of the best sorts from the sixth and fifth levels, and innumerable fine fragments of Attic wares, belonging to the late sixth and fifth centuries B.c., some of which can be recognised as by known artists, from the fourth level point, in Sir Leonard's opinion, not only to a flourishing luxury trade with the Egean, but also to great enterprise on the part of the Athenians in establishing a flourishing commercial centre on this Asiatic coast at a time of tension with the great imperial power of Persia. Evidence was also obtained of intercourse with the Asiatic interior, the occurrence of a basalt bowl, showing a debased Hittite style in decoration, being noted. Such results in a restricted area afford abundant promise from future excavation.

\section{British Standards Institution}

THE annual general meeting of the British Standards Institution was held at the Institution of Mechanical Engineers on June 4, under the chairmanship of Mr. W. Reavell. In reporting on the progress of the work during his year of office, $\mathrm{Mr}$. Reavell made reference to the arbitration in con- nexion with the standards to be adopted in Great Britain for the $16-\mathrm{mm}$. sound films which, at the invitation of the General Council, Lord Riverdale had undertaken in February last, and the decision of which is now being loyally adopted throughout the industry. Mention was also made of the forth. coming visit of the director to New York and the Argentine in connexion with the work of the newly formed Argentine Institute for the Rationalisation of Materials. At the luncheon which followed the meeting, Lord Riverdale referred to the very economic manner in which the work is carried out, dealing as it now does with some eight hundred committees and more than a thousand meetings a year. Some people fear that standardisation means stagnation, but this is provided against in the precautions the B.S.I. takes when standards are brought into being and in the frequent review and revision of those standards. Industry does not fully appreciate the value of standardisation in the matter of capital expenditure. It means the possibility of reduction of stocks which in turn means liberating capital, and this might amount to millions of pounds in the British Empire.

Mr. E. J. Elford, the chairman for the forthcoming year, said that the British Standards Institution is greatly indebted not only to the Government for its continued financial support, to the many technical officers of the various Government departments for their assistance on the technical work, but also to the hundreds of representatives of industryusing that word in the widest sense who give their time and experience so willingly to this work of growing national importance. Mr. S. Tatchell, chairman of the Building Industries National Council, stressed the great importance to the building industry of the closest co-operation between his Council and the B.S.I., and referred to the agreements recently come to which have been set out in their Report on Standardisation Policy. Colonel Briggs, of Messrs. Unilevers, expressed the satisfaction of the chemical industry at the work already undertaken by the Institution in the chemical field and its desire to co-operate in future work of the Institution.

\section{The Development Fund}

THE twenty-fifth report of the Development Commissioners for the year ending March 1935 has now been published (London: H.M. Stationery Office. 2s. 6d. net). The function of the Commissioners is to make a thorough examination of applications for grants from the fund, amending or vetoing the schemes submitted if necessary, and afterwards to recommend to the Treasury what advances shall be made. The majority of the schemes aided call for recurrent expenditure, and as advances are made annually the progress of the work is kept under continuous review. Agriculture and rural economy comprise the main bulk of the expenditure, as under this heading come the regular grants to research institutes, advisory centres and rural industries, as well as the special grants, research scholarships and studentships. A short account of each institute is given, describing the type of work undertaken and 
the number of staff employed. Under the fisheries section, grants are made towards both 'directed' and 'free' research, as it is recognised that much useful information would be lost if only specified lines of research were encouraged. The Development Fund also makes regular advances towards the construction and improvement of harbours and the acquisition of land for road improvements. The total sum recommended in $1934-35$ was $£ 490,968$, compared with $£ 343,636$ in the preceding year, and the report concludes with a detailed summarised schedule of the expenditure.

\section{New Electrical Devices}

IN A.E.G. Progress for the first quarter of 1936 , which is published by the foreign department of the Allgemeine Elektricitäts Gesellschaft of Berlin, the company gives its annual general review of novel electrical devices which are being increasingly used in Germany. One of these is an automatic sequence indicator and timer. In ceramic, chemical and foodstuffs industries, many machines are employed to stir or knead the various ingredients. It is often necessary that these materials be added to the mixture in a definite sequence of time. The new indicator consists of a case containing a number of transparent plates, suitably engraved for each process and lighted up from behind in a predetermined sequence. The attendant is thus warned at the right moment without being obliged to watch the clock. A warning bell is sometimes added to the plate lights. For all kinds of mixing operations this indicator gives useful results. Another device is a 'fan heater' used in conjunction with an electric fire. A silent running fan mounted behind the heating elements circulates the hot air without producing any noticeable draught. The room is quickly and evenly warmed and the hot air can be directed to any point where rapid heating is desired. It is stated that the occupants of a room with a fan heater feel a comfortable warmth on all sides. A switch worked by the foot operates as follows. In position 1 the fan runs cold, operating as a ventilator and using as much power as a small lamp (20 watts) ; in position 2, warm air is emitted, the heater now taking 1,500 watts; and in position 3, it is switched off.

\section{Mineral Development in Canada}

IN a recent series of broadcast addresses, the Minister of Mines at Ottawa emphasised that Canada's vast new mineral wealth is being derived from a line of mining camps extending for 2,400 miles from northern Quebec to Great Bear Lake. Ten years ago, gold production in this belt came from only two districts, whereas to-day mining developments are in progress in a score of separate localities in a region of the Pre-Cambrian shield which is quite unsuitable for agriculture. Thus a new metallic link has been forged between eastern and western Canada which is awakening a new community of interests. The mining camps look to the west for food supplies and to the east for machinery, chemicals, clothing and other factory products. At present the most important section of the new economic frontier is the area including eastern Manitoba, northern Ontario and northern Quebec. Excluding the famous Porcu. pine, Kirkland Lake and Cobalt centres, the Sudbury nickel-copper district, and the eastern Manitoba gold belt, the oldest of the new mines began production only eight years ago. Now there are twenty-eight new mines, and these have given Canada an additional yearly output of gold and copper worth $£ 7,000,000$, a production value more than the annual gold output of Kirkland Lake. The value of the metals produced from this narrow belt alone now exceeds $£ 20,000,000$, while that from Sudbury adds a further $£ 12,000,000$.

\section{Physics at Harvard}

THE new volume of Contributions from the Physical Laboratories of Harvard University consists of reprints of sixty-five papers which have been issued from the laboratories during the years 1933-34. It forms the first volume of Series 2, and its pages are half an inch higher and wider than those of its predecessors. This increase allows papers from double column periodicals like the Physical Review and the Journal of Chemical Physics to be included without change of form, but papers from the one-column proceedings of the American Academy of Arts and Sciences look insignificant on so large a page. The work represented covers almost every branch of physics-general and atomic physics being the theme of about twenty papers, light and electricity about fifteen each, heat about seven and sound and supersonics three, the classification being approximate only. One paper sketches an interesting course of laboratory work for senior students taking up atomic physics. The subjects which appear most often in the titles are the effects of high pressures on the physical properties of materials, and the line and band spectra of substances.

\section{Carnegie Endowment for International Peace}

THE annual report for 1935 of the Division of Intercourse and Education of the Carnegie Endowment for International Peace issued over the signature of Dr. N. Murray Butler, the director, gives an impressive picture of work being done both in the United States and in Europe to develop an inter. national mind and outlook, and particularly in regard to collective security. An unofficial international conference was arranged at Chatham House, London, on March 5-7, 1935, to consider what steps might be taken to restore confidence by promotion of trade and reduction of unemployment, stabilisation of national monetary systems and better organisation of the family of nations to give security and to strengthen the foundations of international peace. Through the organisation of meetings throughout the United States, lectures by visiting Carnegie professors and others, the distribution of books and pamphlets, the arrangement of 'international mind' alcoves in libraries, the international relations clubs, the League of Nations Association and in other ways, the Division has sought to make known the unanimous recom. mendations of the conference and the principles upon which collective security is based.

(Continued on p. 989.) 